\title{
COMPARATIVE STUDY OF METALS AND PHYTOCHEMICAL SCREENING IN AQUEOUS AND ACETONE EXTRACTS OF CALOTROPIS PROCERA AND AJUGA BRACTEOSA
}

\author{
NiSAR, F. $^{1 *}$ - MiRZA, M. A. ${ }^{1}-$ YASMEEN, K. $^{2}-$ CHOUdHARY, M. A. ${ }^{1}-$ WAQAS, M. ${ }^{1}$ \\ ${ }^{I}$ Department of Chemistry, Mirpur University of Science and Technology (MUST) \\ Mirpur-10250 (AJK), Pakistan \\ ${ }^{2}$ Department of Chemistry, Federal Urdu University of Arts, Science and Technology \\ Gulshan-e-Iqbal Campus, Karachi-75300, Pakistan \\ *Corresponding author \\ e-mail:fari.raja_77@yahoo.com \\ (Received $4^{\text {th }}$ Oct 2018; accepted $16^{\text {th }}$ Jan 2019)
}

\begin{abstract}
The main purpose of this study was to evaluate the antioxidant and phytochemical activities and metal contents from leaves, flowers and roots of regional Aak (Calotropis procera Ait.) and Hari Boti (Ajuga Bracteosa Wall.). Distilled water and acetone solvents were used to extract the antioxidants and phytochemical constituents. Diverse antioxidant and phytochemical activities such as flavonoid, phenolic, and flavonol contents, 2, 2-diphenyl-1-picrylhydrazyl (DPPH), $\mathrm{OH}^{\circ}$, and $\mathrm{H}_{2} \mathrm{O}_{2}$ scavenging activities, $\mathrm{Fe}^{+2}$ chelating action, ferric reducing antioxidant power (FRAP), ascorbic acid and phosphomolybdenium complex essay were performed by using reported methods. Atomic absorption spectroscopy was used to evaluate the different metals such as $\mathrm{Pb}, \mathrm{Cd}, \mathrm{Zn}, \mathrm{Fe}, \mathrm{Cu}, \mathrm{Mg}$ and $\mathrm{K}$. The flavonoid contents (expressed as rutin equivalents) stated as $12.01-82.56 \mathrm{mg} / \mathrm{g}$ dry weight were higher than phenolic contents (expressed as gallic acid equivalents) quantified as $26.60-66.60 \mathrm{mg} / \mathrm{g}$ dry weight. Ajuga bracteosa extracts exhibited significant DPPH and OH radical scavenging activities. In all the analyzed samples, the highest concentration of iron $(27.97 \mathrm{mg} / \mathrm{L})$ was displayed by roots of Ajuga Bracteosa. Health risk index (HRI) revealed that level of $\mathrm{Cd}$ in roots and flowers of Calotropis procera and in flowers of Ajuga bracteosa was not safe for the consumption of humans as its concentration exceeded permissible limit.
\end{abstract}

Keywords: ascorbic acid, $\mathrm{Fe}^{+2}$ chelating action, acetone, ferric reducing antioxidant power

\section{Introduction}

Since old times, people are relying onto medicinal plants for their sicknesses. History for medicinal plants may be longstanding concerning illustration of mankind's historical backdrop. Since the mid of the $19^{\text {th }}$ century diverse categories regarding bioactive compounds have been separated, characterized and identified. Among these, a number of compounds played a prime role in the discovery of new drugs. Many medicines manufactured using plant ingredients possess significant amount of alkaloids, tannins, flavonoids, and phenolic compounds, which play effective role in the cure of a variety of degenerative diseases (Ghias et al., 2012; Ali et al., 2015). Antioxidants help on chain softening responses and free radical searching action as well. All radicals have unpaired electrons and are profoundly breakable, also could extricate electrons starting with other particles to accomplish strength bringing on them harm. An over the top processing about reactive oxygen species (ROS) induces the oxidative stress thereby generating harm to DNA, proteins or lipids, and hampering their normal working (Pham-Huy et al., 2008). These biochemical alterations would involve in the aging process, and additionally in a developing rundown for mankind's diseases, for example, cancerous (Ziech et al., 2011), furthermore Alzheimer's disease (Galindo et al., 2010). 
Cancer and cardiovascular diseases are considered main causes of death in United States of America (USA). Approximately, 32\% deaths due to cancer could be evaded by nutritional adaptations. Extracts from curative herbs, vegetables, and fruits possess anticancer activity, akin to hormonal cure and chemotherapy (Wang et al., 2018). Oral doses of Catharanthus roseus flowers' aqueous extract to rats (diabetic) caused remarkable decrease in blood glucose, and decline in lipid profile. This oral administration also controlled the drop off in body weight (Suja, 2018). Fruits, vegetables and grains hold numerous widespread mixtures of phytochemicals. Antioxidants inferred from plants go about as diminishing operators, metal molecule chelators and also free radical scavengers. In the coming years, exceptional consideration are required to be paid towards exploring natural-based cell reinforcement extraction starting with plants such as, phenols, flavonoids and tocopherols (Wojdyłoa et al. 2007; Katalinic et al. 2006). Toxic metals accumulated in medicinal plants grown on contaminated soil might represent a danger to human wellbeing. Indeed purpose of ongoing research should generally be to lower the levels of contaminates. In national priorities list (NPL) of the substances which are established to cause the potential threat to human health because of recognized or alleged toxicity, arsenic ranks at first. Agency for toxic substances and disease registry (ATSDR) prioritizes substances in light of a mix about their toxicity, possibility of mankind's purposes of presentation and also recurrence. Lead, mercury, and cadmium rank at $2^{\text {nd }}, 3^{\text {rd }}$ and $7^{\text {th }}$ positions in the list of toxicants, separately (ATSDR, 2017). Mankind's interaction with metals might happen throughout world related activities principally through inward breath, dermal routes, mining and from water. Furthermore, contaminated food utilization and exposure to polluted air, soil and dust also enhance metal level in humans (Carlin et al. 2016). A thorough survey from claiming phytochemistry, medicinal and universal utilization of Calotropis procera (Aak) and Ajuga bracteosa (Kauri Boti) may be distributed by Ahmed et al. and Mubashir Hussain et al. separately (Ahmed et al. 2005; Mubashir Hussain et al. 2016). Calotropis procera had been used to treat large portions of infections such as ulcers, spoiling about skin, leprosy, piles, bronchial asthma, and illnesses of the liver, abdomen and spleen as well (Kartikar and Basu, 1994). Ajuga bracteosa is over $10-30 \mathrm{~cm}$ in stature also a prised, medicinal, soft, fragrant and villous herb. Furthermore, goes about similarly as antibacterial, anti-inflammatory, astringent, anthelmintic and antifungal. It can be used to cure intestinal infections, fever, phlegm, gout, palsy, amenorrhea and stiffness (Shen et al., 1993; Kaithwas et al., 2012). Different metals play a vital role in human body. Metals are characterized into two categories; fundamental or key metals and unnecessary or harmful metals. Key metals are copper, iron and Zinc, whereas nonessential or lethal metals are cadmium, chromium, lead and mercury. Key metals also become toxic when taken in high amount (Angelova et al., 2004). Intake of metals through intake of polluted therapeutic plants is related to human wellbeing dangers (Khan et al., 2007). Appraisals of wellbeing dangers to metals are as per the following; $\mathrm{Fe}$ is a basic element which limits many body capacities including supply of $\mathrm{O}_{2}$ in the blood. Fe is also fundamental for giving vitality to the body. Praline hydrolase, ribonucleotide reductase, pyruvate oxidase, mitochondrial cytochrome, and tyrosine are the vital catalysts that entail the iron as a cofactor in the human body (Manore et al., 2009).

Copper assumes a central part in metabolism of energy, amalgamation and assurance of collagen protein. Proteins that oblige the Copper (II) particle as a co-variable in the body are superoxide dismutase and cytochrome-c-oxidase. Raised convergence of $\mathrm{Cu}$ in 
human bodies causes many infections like gastrointestinal infection (Turkdogan et al., 2002). High accumulation of lead has troublesome health impacts such as respiratory and dermatogenic issues brought on by ingestion and dermal contacts of polluted soil (Cao et al., 2010; Wang et al., 2009). Abnormal amounts of lead cause hypertension, stomach related and apprehensive clutters, memory and focus issues, muscle and joint torment. Zinc is a critical mineral required for the body. Zinc controls many body functions, similar to resistant and stomach related framework, lessening of stress levels, vitality digestion and curing of wounds. Deficiency of zinc causes numerous infections such as low circulatory strain, development impediment and hindered bone improvement. Cadmium is not viewed as fundamental to human life. Unfriendly wellbeing impacts on individuals are displayed by overabundance cadmium introduction. From 20 to 30 years, cadmium is aggregated in the kidneys for a moderately extensive period and, at high measurements, harm respiratory framework and causes bone sickness. In the study zone these natural plants have been used to cure skin infections, fever, gout and asthma. The point of the available assessment may be to examine the cell reinforcement exercises, furthermore lethal levels for follow metals, additionally assess supplementary metals starting with chosen parts of Ajuga bracteosa and Calotropis procera developed in the region Bhimber AJK, Pakistan, eventually Tom's perusing utilizing different extraction solvents.

\section{Methods and materials}

\section{Instruments/devices used}

Double-beam UV-Visible Spectrophotometer, Model UV-1900, Shimadzo, AA-7000 Atomic Absorption Spectrophotometers, Shimadzo, and diamond saw blades (Cutter Diamond) were used in this study.

\section{Reagents and chemicals}

Folin-ciocalteu, 2, 2-diphenyl-1-picrylhydrazyl (DPPH), ferrozine, hydrogen peroxide, L-ascorbic acid, and Rutin were purchased from Sigma Chemical Co. whereas $\mathrm{H}_{2} \mathrm{SO}_{4}, \mathrm{H}_{3} \mathrm{PO}_{4}, \mathrm{Na}_{3} \mathrm{PO}_{4}, \mathrm{HClO}_{4}, \mathrm{HNO}_{3},\left(\mathrm{CH}_{3}\right)_{2} \mathrm{CO}, \mathrm{Na}_{2} \mathrm{CO}_{3}, \mathrm{NaNO}_{2}, \mathrm{AlCl}_{3}, \mathrm{NaOH}$, $\mathrm{CH}_{3} \mathrm{COONa}$,), $\mathrm{CH}_{3} \mathrm{OH}, \mathrm{FeSO}_{4}, \mathrm{C}_{6} \mathrm{~N}_{6} \mathrm{FeK}_{3}, \mathrm{C}_{2} \mathrm{HCl}_{3} \mathrm{O}_{2}, \mathrm{FeCl}_{3}, \mathrm{HO}_{3} \mathrm{P}, \mathrm{C}_{12} \mathrm{H}_{7} \mathrm{NCl}_{2} \mathrm{O}_{2}$, $\left(\mathrm{NH}_{4}\right)_{6} \mathrm{Mo}_{7} \mathrm{O}_{24}$ were obtained from Merck (Germany).

\section{Sampling area}

The district Bhimber is situated at an altitude of 313 meters above sea level. It is located between latitude: $32-48$ to 33-34 and longitude: 73-55 to 74-45, and has an area of $1516 \mathrm{~km}^{2}$. People living in the rural and urban areas of district Bhimbr frequently use extracts of various parts of medicinal plants such as roots, leaves and flowers to cure ailments. Hence, the district was focused for this study (Fig. 1).

\section{Sampling of diverse parts of plants}

The study was aimed to detect phytochemicals and metals in medicinal plants collected from hilly areas of Bhimber Azad Jammu and Kashmir, Pakistan. Initially, a physical survey was carried out to select the sampling stations. Fresh flower, leaf and root samples (1-1.5 kg wet weight) of the targeted plants were collected separately in 
polythene bags from pre-decided locations during spring season of the year 2018. The samples were authenticated at the Department of Botany, Mirpur University of Science and Technology (MUST), Mirpur-10250 (AJK), Pakistan. The flowers and leafs were plucked with gloved hands whereas the diamond saw blades purchased from local market were used to cut and collect the root samples. Then, to remove soil particles, the collected plants' parts were washed carefully with tap water and distilled water respectively. The plants' parts were cut into small pieces and left to dry them out in mild sunlight for a number of days. The commercial beater was used to convert dried parts of the plants into coarse powder. The dried and powdered samples packed in prewashed polythene bags were shifted to the lab for wet digestion and metal analysis.

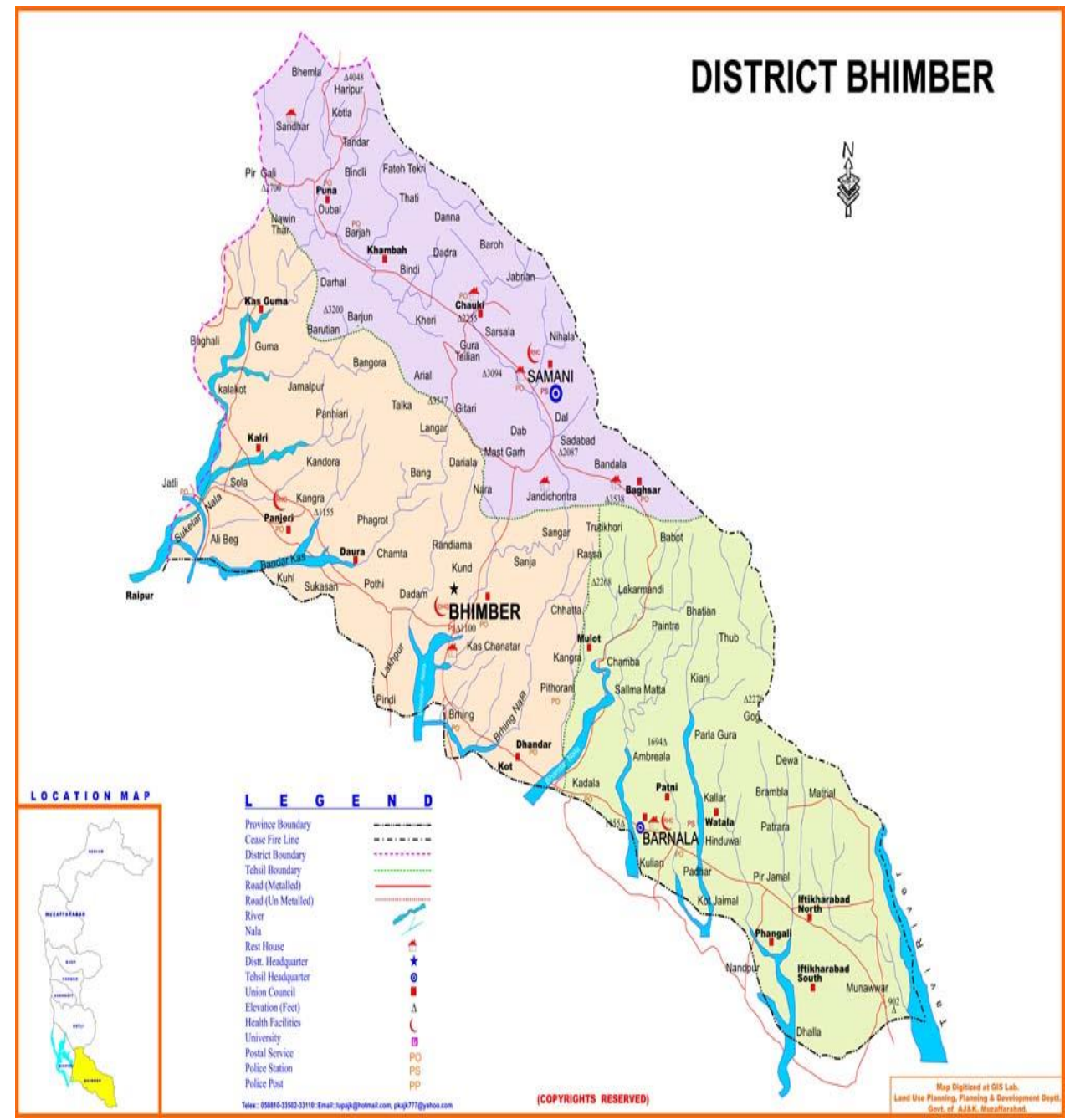

Figure 1. Map of district Bhimber, the sampling area

\section{Digestion of plants' parts for metal analysis}

Digestion protocol explained by Sharma et al. (2008) was followed. Various parts of the plant samples (powdered) were digested using the fixed ratio of concentrated $\mathrm{H}_{2} \mathrm{SO}_{4}, \mathrm{HNO}_{3}$ and $\mathrm{HClO}_{4}$. For this purpose, mixture of conc. sulphuric acid, perchloric acid and nitric acid (1:1:5) was utilised. One g of powdered plant sample taken in beaker was added $15 \mathrm{~mL}$ of acid mixture. The sample in beaker was heated for digestion at 
$70{ }^{\circ} \mathrm{C}$ on hot plate in a fume hood. In order to avoid the evaporation of metal contents, the digestion process was carried out at slow rate. Near to dryness, $10 \mathrm{~mL}$ of acid mixture were added again and the temperature was increased slowly upto $90{ }^{\circ} \mathrm{C}$ to get around 5-8 $\mathrm{mL}$ of clear digested solution. Then, the cooled digested solution in the beaker was added $15 \mathrm{~mL}$ of nitric acid $(0.05 \mathrm{~N})$ and filtered by using Whatsman filter paper no. 41. The volume of the filtered digest was made upto $30 \mathrm{~mL}$ with $0.05 \mathrm{~N}$ nitric acid solution and stored at $4{ }^{\circ} \mathrm{C}$ in pre-washed, dried polythene bottles for metal analysis (Sharma et al., 2008).

\section{Extraction of the plant samples for analysis of phytochemicals}

Two-step extraction procedure was adopted for the investigation of antioxidant activity and phytochemical components. Water and acetone solvents were used in first and second steps for the extraction of hydrophilic and hydrophobic contents respectively.

For water extraction, $1 \mathrm{~g}$ powdered plant sample in $10 \mathrm{~mL}$ distilled water was centrifuged for $20 \mathrm{~min}$ at $6000 \mathrm{rpm}$ and supernatant was shifted to a test tube. The same extraction practice was repeated thrice and each time upper layer was collected in the test tube. The solid residue left after the water extraction was further extracted three times using acetone $(1: 10 \mathrm{w} / \mathrm{v})$ and the supernatant layer was saved in another test tube. Both the extracts containing phytochemical ingredients were stored at $-10{ }^{\circ} \mathrm{C}$ to carry out further analysis in the department of Chemistr, Mirpur University of Science and Technology, Mirpur, which is situated at Pakistan country in the cities place category with the GPS coordinates of $73^{\circ} 45^{\prime} 6.3720^{\prime \prime} \mathrm{E}$ and $33^{\circ} 8^{\prime} 54.2112^{\prime \prime} \mathrm{N}$.

\section{Investigation of phenolic contents}

The investigation of phenolic contents in water and $\left(\mathrm{CH}_{3}\right)_{2} \mathrm{CO}$ concentrates was finished with the assistance of the strategy depicted by Jing et al. (2015). Above all, arranged the ten time's diluted Folin-ciocalteu by including one $\mathrm{mL}$ Folin-ciocalteu, finished the level up to ten $\mathrm{mL}$ with distilled $\mathrm{H}_{2} \mathrm{O}$. Around $1 \mathrm{~mL}$ of $\mathrm{H}_{2} \mathrm{O}$ and $\left(\mathrm{CH}_{3}\right)_{2} \mathrm{CO}$ concentrate was mixed with $5 \mathrm{~mL}$ of diluted Folin-ciocalteu and $4 \mathrm{~mL}$ of $7.5 \% \mathrm{Na}_{2} \mathrm{CO}_{3}$. Before measuring spectrophotometrically the absorbance at $760 \mathrm{~nm}$, left the blend at room temperature to $90 \mathrm{~min}$.

\section{Investigation of flavonoids contents}

Recognition of flavonoids was finished with the assistance of strategy altered by Jing et al. (2015). Around $5 \mathrm{~mL}$ of $\mathrm{H}_{2} \mathrm{O}$ or $\left(\mathrm{CH}_{3}\right)_{2} \mathrm{CO}$ concentrates were added into $0.3 \mathrm{~mL}$ of $5 \% \mathrm{NaNO}_{2}$ for $5 \mathrm{~min}$, and then included $0.3 \mathrm{~mL}$ of $10 \% \mathrm{AlCl}_{3}$ in the certain blend. Two $\mathrm{mL}$ of $1 \mathrm{M} \mathrm{NaOH}$ was included the blend to discontinue the response after six min. The surrendered blend was diluted to $10 \mathrm{~mL}$ and calculated the absorbance quickly at $510 \mathrm{~nm}$. Rutin was utilized as standard and flavonoids were explained as rutin counterparts.

\section{Investigation of flavonols}

Flavonols in the samples were recognized by utilizing the strategy set by Kumaran and Karunakaran (2006). Around $2 \mathrm{~mL}$ of $\mathrm{H}_{2} \mathrm{O}$ or $\left(\mathrm{CH}_{3}\right)_{2} \mathrm{CO}$ concentrate mixed with $2 \mathrm{~mL}$ of $(50 \mathrm{~g} / \mathrm{L}) \mathrm{CH}_{3} \mathrm{COONa}$ and $2 \mathrm{~mL}$ of $2 \%$ aluminium chloride in the concentrate. 
The blend was permitted to left for $2.5 \mathrm{~h}$ and then measured the absorbance at $440 \mathrm{~nm}$. Rutin was utilized as a standard for the detection of flavonols using calibration curve equation $y=0.0007 x+0.3591(x=$ concentration of rutin, $y=$ absorbance $)$.

\section{Scavenging activity of DPPH}

Scavenging action of DPPH (2, 2-diphenyl-1-picrylhydrazyl) was documented by the strategy portrayed by Yu et al. (2002) and Aoshima et al. (2004). Around $1 \mathrm{~mL}$ of the specimen concentrate was added in $2.5 \mathrm{~mL}$ of DPPH $\left(0.1 \mathrm{mM}\right.$ in $\left.\mathrm{CH}_{3} \mathrm{OH}\right)$ and held the blend in darkness for $30 \mathrm{~min}$. At $517 \mathrm{~nm}$, vanishing of the shade of DPPH was measured against the clear. The outcomes were measured as Equation 1:

$$
\% \text { inhibition }=\frac{\text { A Blank }- \text { A Sample }}{\text { A Blank }} \times 100
$$

\section{Scavenging activity of $\mathrm{OH}^{\circ}$}

The scavenging activity of $\mathrm{OH}^{\circ}$ of concentrates of plants in $\mathrm{H}_{2} \mathrm{O}$ and $\left(\mathrm{CH}_{3}\right)_{2} \mathrm{CO}$ was portrayed by $\mathrm{Yu}$ et al. (2004). Around $3 \mathrm{~mL}$ of $\mathrm{H}_{2} \mathrm{O}$ or $\left(\mathrm{CH}_{3}\right)_{2} \mathrm{CO}$ concentrate was mixed in $1 \mathrm{~mL}$ of $\mathrm{C}_{12} \mathrm{H}_{8} \mathrm{~N}_{2}(0.04 \mathrm{M}), 2 \mathrm{~mL}$ phosphate buffer $(0.2 \mathrm{M})$, and $0.04 \mathrm{~L}$ of $\mathrm{FeSO}_{4}(0.02 \mathrm{M})$. The reaction was begun by the addition of $0.1 \mathrm{~mL}$ of $7.0 \mathrm{mM}$ hydrogen peroxide in the blend, and then measured absorbance at $560 \mathrm{~nm}$. The scavenging activity was evaluated as expressed in Equation 2:

$$
\text { Scavenging activity }=\frac{\text { A Blank }- \text { A Sample }}{\text { A Blank }} \times 100
$$

\section{Scavenging activity of hydrogen peroxide}

Aiyegoro and Okoh (2010) reported the method for the measurement of scavenging activity of $\mathrm{H}_{2} \mathrm{O}_{2}$. The $2.4 \mathrm{~mL}$ of hydrogen peroxide solution $(4 \mathrm{mM})$ prepared in $0.1 \mathrm{M}$ phosphate buffer ( $\mathrm{pH} 7.4$ ) was blended with $4 \mathrm{~mL}$ extract and incubated for $10 \mathrm{~min}$ at room temperature, then measured absorbance at $230 \mathrm{~nm}$ against the blank (Reimann and de Caritat, 2005). Scavenging activity was calculated as Equation 3:

$$
\text { Scavenging activity }=\frac{\text { A Blank }- \text { A Sample }}{\text { A Blank }} \times 100
$$

\section{Chelating action of $\mathrm{Fe}^{+2}$}

The chelating capacity of $\mathrm{Fe}^{+2}$ ions was evaluated via the technique for Dinis et al. (1994). Around $2 \mathrm{~mL} \mathrm{FeSO}_{4}(0.125 \mathrm{mM})$ was mixed with $2 \mathrm{~mL}$ of water or $\left.\mathrm{CH}_{3}\right)_{2} \mathrm{CO}$ extracts. Two $\mathrm{mL}$ ferrozine $(0.3125 \mathrm{mM})$ was added into the blend to start the reaction and left the blend for ten min. The absorbance was measured at $562 \mathrm{~nm}$ against the blank. The accompanying equation was utilized to ascertain chelating action (Eq. 4):

$$
\text { Chelating Activity }=\frac{(\text { A control }- \text { A Sample })}{(\text { A control })} \times 100
$$

\section{Ferric reducing antioxidant power (FRAP)}

Hazara et al. described the method for the detection of ferric lessening cancer prevention agent control (Hazara et al., 2008). Around $2 \mathrm{~mL}$ of concentrate was blended 
with the two $\mathrm{mL}$ phosphate buffer $\left(0.2 \mathrm{M}, \mathrm{pH}\right.$ 6.6) and two $\mathrm{mL}$ of $0.1 \% \mathrm{C}_{6} \mathrm{~N}_{6} \mathrm{FeK}_{3}$ and held the mixture for twenty $\min$ at $50{ }^{\circ} \mathrm{C}$. Subsequent to twenty min, the reaction was clogged by two $\mathrm{mL} \mathrm{C}_{2} \mathrm{HCl}_{3} \mathrm{O}_{2}(10 \%)$. The supernants were blended with $2 \mathrm{~mL}$ of $\mathrm{FeCl}_{3}$ and $2 \mathrm{~mL}$ of $\mathrm{H}_{2} \mathrm{O}$ and permitted to remain for $20 \mathrm{~min}$ and afterward absorbance was measured at $700 \mathrm{~nm}$ aligned with the clear. Ascorbic corrosive was utilized as positive control.

\section{Ascorbic acid determination}

Ascorbic corrosive substances were controlled by the strategy as expressed by Klein and Perry (1982). Dry water extract was re-extricated for $\mathrm{HO}_{3} \mathrm{P}(1 \%, 10 \mathrm{~mL})$ to $45 \mathrm{~min}$ and then filtered. $1 \mathrm{~mL}$ filtrate was blended in $9 \mathrm{~mL} \mathrm{C}_{12} \mathrm{H}_{7} \mathrm{NCl}_{2} \mathrm{O}_{2}(0.8 \mathrm{~g} / 1000 \mathrm{~mL})$ and then measured absorbance inside thirty $\mathrm{min}$ at $515 \mathrm{~nm}$. Ascorbic substances computed from L-ascorbic acid bend $\left(0.006-0.1 \mathrm{mg} / \mathrm{mL} ; \mathrm{y}=3.006 \mathrm{x}+0.007 ; \mathrm{R}^{2}=0.999\right)$, and results were communicated as ascorbic corrosive equivalents.

\section{Phosomolybdenium complex assay}

Prieto et al. described the method to measure Phosomolybdenium complex of the extracts spectrophotometrically (Prieto et al., 2006). Quickly $2 \mathrm{~mL}$ of sample in $\mathrm{H}_{2} \mathrm{O}$ or $\left.\mathrm{CH}_{3}\right)_{2} \mathrm{CO}$ was mixed in $6.6 \mathrm{~mL}$ claiming reagent $\left(28 \mathrm{~mol} / \mathrm{L} \mathrm{Na}_{3} \mathrm{PO}_{4}, 0.6 \mathrm{molL}^{-1}\right.$ sulphuric acid and $4 \mathrm{molL}^{-1}\left(\mathrm{NH}_{4}\right)_{6} \mathrm{Mo}_{7} \mathrm{O}_{24}$ topped the mixture and incubated at $95{ }^{\circ} \mathrm{C}$ for $90 \mathrm{~min}$. After cooling, the absorbance was measured at $695 \mathrm{~nm}$ alongside reasonable holding one $\mathrm{mL}$ of reagent and also one $\mathrm{mL} \mathrm{H}_{2} \mathrm{O}$ rather than extracts and after that subjected to the same exploratory conditions. The outcomes from three examinations, each kept running in triplicate, were communicated as the mean of relative antioxidant action (RAA) compared with that of vitamin-C.

\section{Daily intake of metals (DIM)}

Information regarding the daily ingestion of therapeutic plants was gathered during the study. DIM was computed as Equation 5:

$$
\mathrm{DIM}=\frac{\text { Cmetal } \times \text { CFactor } \times \text { Cfood intake }}{\text { Baverage weight }}
$$

$\mathrm{C}_{\text {metal }}$ stands for metal contents in selected samples, $\mathrm{C}_{\text {Factor }}$ depicts the conversion factor (value is 0.083), $\mathrm{C}_{\text {food intake }}$ utilization of therapeutic plants which is $100 \mathrm{mg}$ per individual per day and $\mathrm{B}_{\text {average weight }}$ corresponds to the normal body weight within review range which is $50 \mathrm{~kg}$.

\section{Health risk index (HRI)}

$$
\mathrm{HRI}=\mathrm{DIM} / \mathrm{RfD}
$$

RfD characterizes the reference oral measurement. The value of health risk index less than one represents the protected mode for nearby populace through intake of plants and the other way around (Eq. 6 ). 


\section{Results and discussion}

\section{Flavonoids, flavonols and total phenol contents of the extracts}

It has been identified that flavonoids show cell reinforcement endeavour and their outcomes on ethnical nourishment then wellbeing are impressive. Several recent studies have confirmed that phytochemicals including alkaloids, flavonoids, flavonols, phenols, terpenoids and steroids have colossal antioxidant and free radical scavenging activities. Plant extracts rich in polyphenols and essential phytoconstituents have been shown to display persuasive antioxidant and free radical scavenging activities in diverse antioxidant models (Farhan et al., 2012; Amari et al., 2014).

The flavonoids, flavonols and phenols are important as their hydroxyl groups are accountable for antioxidant effects in plants. Highest flavonoid contents were shown by water extract of leaves of Ajuga bracteosa $(81.56 \mathrm{mg} / \mathrm{g})$ and least contents $(12.01 \mathrm{mg} / \mathrm{g}$ ) were present in roots of Calotropis procera (Table 1). Leaves and flowers of Calotropis procera showed highest flavonol contents in water and acetone extracts respectively $(98.98 \mathrm{mg} / \mathrm{g}, 60.27 \mathrm{mg} / \mathrm{g})$. Least flavonol contents were present in water and acetone extracts of roots of Ajuga bracteosa $(82.71 \mathrm{mg} / \mathrm{g})$. Phenolic substance are measured as far as gallic equivalents having highest contents in leaves of Ajuga bracteosa $(66.60$ $\mathrm{mg} / \mathrm{g}$ ) followed by leaves of Calotropis procera (Table 1).

Table 1. Phytochemical constituents in leaves, flowers and roots of Ajuga bracteosa and Calotropis procera

\begin{tabular}{c|c|c|c|c|c|c|c|c}
\hline \multirow{2}{*}{$\begin{array}{c}\text { Botanical name of } \\
\text { therapeutic plants }\end{array}$} & \multirow{2}{*}{$\begin{array}{c}\text { Part of the } \\
\text { plant taken }\end{array}$} & \multirow{2}{*}{$\begin{array}{c}\text { Local } \\
\text { name }\end{array}$} & \multicolumn{2}{c|}{$\begin{array}{c}\text { Total phenolic } \\
\text { contents (mg/g) }\end{array}$} & \multicolumn{2}{c|}{$\begin{array}{c}\text { Flavonoid } \\
\text { contents (mg/g) }\end{array}$} & \multicolumn{2}{c}{$\begin{array}{c}\text { Flavonol } \\
\text { contents (mg/g) }\end{array}$} \\
\cline { 4 - 9 } & & & Water & Acetone & Water & Acetone & Water & Acetone \\
\hline Ajuga bracteosa & Leaves & Hari Boti & 66.60 & 56.10 & 81.56 & 40.77 & 20.48 & 15.44 \\
Ajuga bracteosa & Flowers & Hari Boti & 26.60 & 24.95 & 30.21 & 28.84 & 47.81 & 25.74 \\
Ajuga bracteosa & Roots & Hari Boti & 60.43 & 53.63 & 43.54 & 31.41 & 82.71 & 24.75 \\
Calotropis procera & Flowers & Aak & 59.67 & 21.26 & 32.62 & 26.72 & 60.27 & 16.83 \\
Calotropis procera & Leaves & Aak & 60.67 & 41.20 & 82.56 & 14.10 & 98.98 & 35.73 \\
Calotropis procera & Roots & Aak & 43.17 & 11.25 & 12.01 & 12.54 & 42.62 & 23.61 \\
\hline
\end{tabular}

\section{Antioxidant activity}

The antioxidants from the leaves, roots and flowers of Ajuga bracteosa and Calotropis procera extracted in water and acetone are shown in Table 2.

The free radical scavenging activity of both hydrophilic and lipophilic antioxidants is estimated by the DPPH radical that is a stable free radical, and has been widely used as a sensitive and rapid tool. DPPH interact with antioxidants that neutralize the free radicals by transferring electrons or hydrogen atoms to DPPH (Archana et al., 2005). Watery extract of flowers of Ajuga bracteosa showed highest DPPH scavenging activity $(97 \%)$ over roots and leaves $(96 \%, 94 \%)$. The $\mathrm{OH}$ radical has been considered as a highly damaging ROS in free radical pathology, has ability to damage almost every molecule in living cells. The hydroxyl radical scavenging capacity of therapeutic plants is directly related to their antioxidant activity (Uttara et al., 2009). Roots of Ajuga bracteosa and leaves of Calotropis procera gave the same $\mathrm{OH}$ radical and hydrogen peroxide scavenging activity respectively in aqueous extracts $(77 \%)$, while acetone 
extracts gave the poor $\mathrm{OH}$ radical and hydrogen peroxide scavenging activities. The higher antioxidant yield from leaves and blooms of Ajuga bracteosa and Calotropis procera with water solvent prominently indicate viability of this solvent towards antioxidant components from these materials.

Table 2. Antioxidant activities in leaves, flowers and roots of Ajuga bracteosa and Calotropis procera

\begin{tabular}{|c|c|c|c|c|c|c|c|c|}
\hline \multirow[t]{2}{*}{$\begin{array}{c}\text { Botanical name of } \\
\text { therapeutic } \\
\text { plants }\end{array}$} & \multirow[t]{2}{*}{$\begin{array}{c}\text { Part of } \\
\text { the plant } \\
\text { taken }\end{array}$} & \multirow[t]{2}{*}{$\begin{array}{l}\text { Local } \\
\text { name }\end{array}$} & \multicolumn{2}{|c|}{$\begin{array}{c}\text { DPPH scavenging } \\
\text { activity (\%) }\end{array}$} & \multicolumn{2}{|c|}{$\begin{array}{l}\text { OH radical } \\
\text { scavenging } \\
\text { activity }(\%)\end{array}$} & \multicolumn{2}{|c|}{$\begin{array}{c}\text { Hydrogen } \\
\text { peroxide radical } \\
\text { scavenging } \\
\text { activity }(\%)\end{array}$} \\
\hline & & & Water & Acetone & Water & Acetone & Water & Acetone \\
\hline Ajuga bracteosa & Leaves & Hari Boti & 94 & 81 & 30 & 48 & 23 & 02 \\
\hline Ajuga bracteosa & Flowers & Hari Boti & 57 & 47 & 57 & 15 & 21 & 13 \\
\hline Ajuga bracteosa & Roots & Hari Boti & 96 & 88 & 77 & 16 & 40 & 04 \\
\hline Calotropis procera & Flowers & Aak & 94 & 77 & 75 & 14 & 78 & 16 \\
\hline Calotropis procera & Leaves & Aak & 89 & 87 & 59 & 8 & 77 & 51 \\
\hline Calotropis procera & Roots & Aak & 73 & 55 & 42 & 06 & 76 & 23 \\
\hline
\end{tabular}

\section{Metal chelating action}

The chelating of $\mathrm{Fe}^{+2}$ by different plant extracts is evaluated via the method utilized by Dinis et al. (1994). Different studies revealed that the reducing power of biologically active compounds relative to their antioxidant action is reflected by the electron donation capability. Antioxidants are reducing agents, and inactivation of oxidants by reductants can be described as a reduction-oxidation (redox) reaction, in which one reaction species is reduced at the expense of the oxidation of the other (Gulcin et al., 2010). In the reducing power assay, the presence of antioxidants in the therapeutic plants would cause the reduction of $\mathrm{Fe}_{3}{ }^{+}$to $\mathrm{Fe}_{2}{ }^{+}$by donating the electron. Aqueous extract of leaves of Ajuga bracteosa was the most active extract interfered with the formation of ferrous and ferrozine complex, that is connected with redox metal catalysis incorporates chelating in regards to the metal particles before ferrozine followed by chelating activity of roots and flowers of Ajuga bracteosa, then, leaves of Calotropis procera. Acetone extracts showed less chelating activity towards $\mathrm{Fe}^{+2}$ (Table 3).

Table 3. $\mathrm{Fe}^{+2}$ chelating activity and FRAP activity in leaves, flowers and roots of Ajuga bracteosa and Calotropis procera

\begin{tabular}{|c|c|c|c|c|c|c|}
\hline \multirow{2}{*}{$\begin{array}{l}\text { Botanical name of } \\
\text { therapeutic plants }\end{array}$} & \multirow{2}{*}{$\begin{array}{l}\text { Part of the } \\
\text { plant taken }\end{array}$} & \multirow[t]{2}{*}{ Local name } & \multicolumn{2}{|c|}{$\begin{array}{c}\mathrm{Fe}^{+2} \text { chelating activity } \\
(\%)\end{array}$} & \multicolumn{2}{|c|}{ FRAP activity (\%) } \\
\hline & & & Water & Acetone & Water & Acetone \\
\hline Ajuga bracteosa & Leaves & Hari Boti & 67 & 10 & 68 & 43 \\
\hline Ajuga bracteosa & Flowers & Hari Boti & 33 & 10 & 71 & 50 \\
\hline Ajuga bracteosa & Roots & Hari Boti & 56 & 68 & 82 & 62 \\
\hline Calotropis procera & Flowers & Aak & 17 & 21 & 78 & 82 \\
\hline Calotropis procera & Leaves & Aak & 46 & 34 & 69 & 75 \\
\hline Calotropis procera & Roots & Aak & 43 & 11 & 32 & 26 \\
\hline
\end{tabular}


Table 3 showed the ferric reducing antioxidant power (FRAP) activity in different parts of Ajuga bracteosa and Calotropis procera in aqueous and acetone extracts. Acetone extracts of Calotropis procera showed highest FRAP activity followed by water extracts of Ajuga bracteosa.

\section{Phosomolybdenium complex assay and ascorbic acid determination}

Phosphomolybdenium assay was expressed as mg AAE/100 g (Table 4).

Roots of Ajuga bracteosa and flowers of Calotropis procera showed significantly higher values in aqueous extract $(212.9 \mathrm{mg} / \mathrm{g}, 207.65 \mathrm{mg} / \mathrm{g})$ respectively. Aqueous extract of flowers of Ajuga bracteosa showed the second higher contents $(100 \mathrm{mg} / \mathrm{g})$. Lower contents were observed in acetone extracts of flowers of Ajuga bracteosa and leaves of Calotropis procera $(6.0 \mathrm{mg} / \mathrm{g}, 6.65 \mathrm{mg} / \mathrm{g})$. Significantly differences in ascorbic acid contents among different parts of two plants were recorded (Table 4). Flowers of Ajuga bracteosa and Calotropis procera had the highest and same ascorbic acid contents $(0.469 \mathrm{mg} / \mathrm{g})$ followed by roots of Ajuga bracteosa $(0.379 \mathrm{mg} / \mathrm{g})$. Lower contents were observed in roots of Calotropis procera $(0.121 \mathrm{mg} / \mathrm{g})$.

Table 4. Phosomolybdenium complex assay and ascorbic acid contents in leaves, flowers and roots of Ajuga bracteosa and Calotropis procera

\begin{tabular}{c|c|c|c|c|c}
\hline \multirow{2}{*}{$\begin{array}{c}\text { Botanical name of } \\
\text { therapeutic plants }\end{array}$} & \multirow{2}{*}{$\begin{array}{c}\text { Part of the } \\
\text { plant taken }\end{array}$} & \multirow{2}{*}{ Local name } & \multicolumn{2}{|c|}{$\begin{array}{c}\text { Phosomolybdenium complex } \\
\text { assay (mg/g) }\end{array}$} & $\begin{array}{c}\text { Ascorbic acid } \\
\text { determination } \\
\text { (mg/g) }\end{array}$ \\
\cline { 4 - 5 } & & Water & Acetone & 0.261 \\
Ajuga bracteosa & Leaves & Hari Boti & 64.4 & 38.65 & 0.469 \\
Ajuga bracteosa & Flowers & Hari Boti & 100.15 & 6.0 & 0.379 \\
Ajuga bracteosa & Roots & Hari Boti & 212.9 & 13.9 & 0.469 \\
Calotropis procera & Flowers & Aak & 207.65 & 15.90 & 0.261 \\
Calotropis procera & Leaves & Aak & 38.90 & 6.65 & 0.121 \\
Calotropis procera & Roots & Aak & 47.20 & 21.50 & \\
\hline
\end{tabular}

\section{Distribution of metals}

Sources of different metals in soil, plants and water are anthropogenic activities and furthermore from parent materials; however it is hard to assess the ordinary foundation groupings of metals in soil, water and plants (Reimann and de Caritat, 2005). Thus it is surveyed that centralization of metals contains both a trademark geochemical partition and anthropogenic exercises (Acosta et al., 2010). The distribution of metals among selected plants is represented in Table 5. Except lead, all metals are present in considerable concentrations. Highest mean level is shown by iron followed by zinc. The decreasing order of concentration of metals is as follows; $\mathrm{Fe}>\mathrm{Zn}>\mathrm{Cu}>\mathrm{Ni}>\mathrm{Cd}>\mathrm{Pb}$. The relationship study was likewise done to evaluate the shared varieties of chose metals in selected plants.

The correlation coefficients of selected metals in medicinal plants are shown in Table 6. Compact disc $\mathrm{Fe}(\mathrm{r}=0.756)$ and $\mathrm{Fe}-\mathrm{Cu}(\mathrm{r}=0.633)$ depicted the positive association. Be that as it may, exceptionally solid positive connection was appeared by $\mathrm{Pb}-\mathrm{Ni}(\mathrm{r}=0.839)$. Strongest connection was appeared by $\mathrm{Zn}-\mathrm{Fe}(\mathrm{r}=0.869)$ and $\mathrm{Zn}-\mathrm{Cd}$ $(\mathrm{r}=0.851)$, showing their conceivable basic starting point. 
Table 5. Concentration $(\mathrm{mg} / \mathrm{kg})$ of metal contents in extracts of leaves, flowers and roots of selected medicinal plants $(n=3)$

\begin{tabular}{c|c|c|c|c|c|c}
\hline Samples & Pb & $\mathbf{N i}$ & $\mathbf{Z n}$ & $\mathbf{C d}$ & $\mathbf{F e}$ & $\mathbf{C u}$ \\
\hline \multirow{2}{*}{ Ajuga bracteosa, leaves } & \multirow{2}{*}{$\mathrm{BDL}$} & $0.092 \pm$ & $0.449 \pm$ & $0.104 \pm$ & $8.678 \pm$ & $0.084 \pm$ \\
& & 0.005 & 0.010 & 0.011 & 0.001 & 0.055 \\
Ajuga bracteosa, flowers & $\mathrm{BDL}$ & $0.177 \pm$ & $0.500 \pm$ & $0.100 \pm$ & $12.83 \pm$ & $0.106 \pm$ \\
& & 0.035 & 0.013 & 0.051 & 0.025 & 0.012 \\
Ajuga bracteosa, roots & $\mathrm{BDL}$ & $0.113 \pm$ & $0.608 \pm$ & $0.105 \pm$ & $27.97 \pm$ & $0.279 \pm$ \\
& & 0.031 & 0.004 & 0.005 & 0.105 & 0.051 \\
Calotropis procera, leaves & $0.015 \pm$ & $0.171 \pm$ & $0.277 \pm$ & $0.096 \pm$ & $6.910 \pm$ & $0.122 \pm$ \\
& 0.001 & 0.105 & 0.501 & 0.012 & 0.001 & 0.001 \\
Calotropis procera flowers & $\mathrm{BDL}$ & $0.122 \pm$ & $0.307 \pm$ & $0.094 \pm$ & $4.045 \pm$ & $0.164 \pm$ \\
& & 0.010 & 0.050 & 0.016 & 0.018 & 0.005 \\
Calotropis procera roots & $\mathrm{BDL}$ & $0.136 \pm$ & $0.421 \pm$ & $0.097 \pm$ & $7.281 \pm$ & $0.214 \pm$ \\
& & 0.016 & 0.007 & 0.009 & 0.105 & 0.004 \\
\hline
\end{tabular}

BDL stands for below detection limit

Table 6. Correlation co-efficient of selected metals in therapeutic plants

\begin{tabular}{l|c|c|c|c|c}
\hline & $\mathbf{P b}$ & $\mathbf{N i}$ & $\mathbf{Z n}$ & $\mathbf{C d}$ & $\mathbf{F e}$ \\
\hline $\mathbf{N i}$ & $\mathbf{0 . 8 3 9}$ & & & & \\
$\mathbf{Z n}$ & -0.308 & -0.279 & & & \\
$\mathbf{C d}$ & -0.402 & -0.471 & $\mathbf{0 . 8 5 1}$ & & \\
$\mathbf{F e}$ & -0.208 & -0.178 & $\mathbf{0 . 8 6 9}$ & $\mathbf{0 . 7 5 6}$ & \\
$\mathbf{C u}$ & -0.109 & -0.243 & 0.459 & 0.160 & $\mathbf{0 . 6 3 3}$ \\
\hline
\end{tabular}

$\mathrm{P} \leq 0.05$ Significant

Cluster investigation of metals was done so as to study the multivariate seizure as appeared as dandrogram in Figure 2. Cluster examination gives the huge information on the premise of comparable qualities. Three clusters were observed for selected metals. First cluster exhibited close association of metals ( $\mathrm{Zn}, \mathrm{Fe}$, and $\mathrm{Cd}$ ). Cluster of $\mathrm{Cu}$ showed mutual relationship with first cluster depicted that the metal concentrations vary because of basic components of the soil minerals and they have lithogenic cause. Third Cluster was appeared by $\mathrm{Ni}$ and $\mathrm{Pb}$ which also entangled with other clusters revealed that this association may be contributed by the horticultural exercises and additionally dry statement of the suspended particulates.

The quartile circulation of metals in therapeutic plants is shown in Figure 2. Symmetric distribution was shown by essential metal i.e. iron. Narrow distribution was shown by $\mathrm{Ni}, \mathrm{Pb}, \mathrm{Cu}$ and $\mathrm{Cd}$. on the ability about dirt towards a multivariable-based cation profession get ready fundamentally liable to physicochemical conditions, for example, $\mathrm{pH}$, temperature and the propinquity of different particles within the dirt structure. Description of health risk assessment is represented in Table 7. Health risk index revealed that some metals have safe level in selected plants so that some parts of selected therapeutic plants can be used as drug development and as a supplement to human body. Higher levels of cadmium and iron are investigated by consuming different parts of selected plants. 


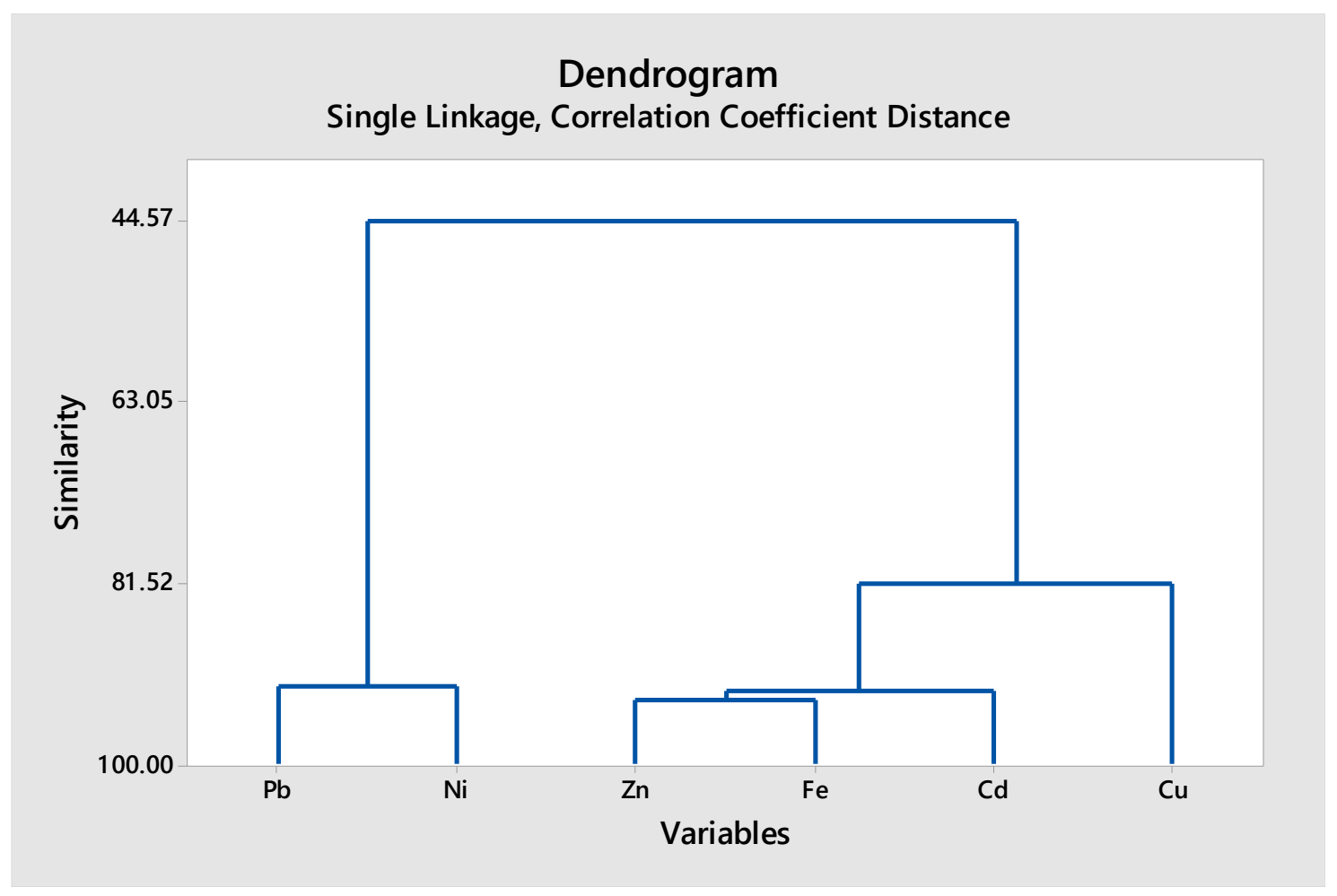

Figure 2. Cluster investigation of metals

Table 7. Description of health risk assessment of metals in selected parts of the plants

\begin{tabular}{|c|c|c|c|c|c|c|c|c|c|c|c|c|}
\hline \multirow{3}{*}{$\begin{array}{c}\text { RfD } \\
\text { Plants and } \\
\text { their parts }\end{array}$} & \multicolumn{6}{|c|}{ DIM (mg/day) } & \multicolumn{6}{|c|}{ HRI } \\
\hline & \multicolumn{3}{|c|}{ Ajuga bracteosa } & \multicolumn{3}{|c|}{ Calotropis procera } & \multicolumn{3}{|c|}{ Ajuga bracteosa } & \multicolumn{3}{|c|}{ Calotropis procera } \\
\hline & $\mathbf{L}$ & $\mathbf{R}$ & $\mathbf{F}$ & $\mathbf{L}$ & $\mathbf{R}$ & $\mathbf{F}$ & $\mathbf{L}$ & $\mathbf{R}$ & $\mathbf{F}$ & $\mathbf{L}$ & $\mathbf{R}$ & $\mathbf{F}$ \\
\hline $\mathrm{Cu}^{\mathrm{b}} 0.040$ & 0.014 & 0.046 & 0.018 & 0.020 & 0.055 & 0.027 & 0.35 & 1.15 & 0.43 & 0.50 & 0.88 & 0.68 \\
\hline $\mathrm{Ni}^{\mathrm{b}} 0.020$ & 0.015 & 0.018 & 0.029 & 0.028 & 0.023 & 0.202 & 0.75 & 0.90 & 1.47 & 1.40 & 1.13 & 1.01 \\
\hline $\mathrm{Cd}^{\mathrm{b}} 0.001$ & 0.012 & 0.017 & 0.017 & 0.016 & 0.016 & 0.016 & 12.4 & 1.74 & 16.6 & 0.002 & 16 & 15.6 \\
\hline $\mathrm{Zn}^{\mathrm{b}} 0.300$ & 0.075 & 0.100 & 0.075 & 0.046 & 0.070 & 0.051 & 0.25 & 0.33 & 0.25 & 0.153 & 0.94 & 0.17 \\
\hline $\mathrm{Pb}^{\mathrm{b}} 0.0036$ & $\mathrm{BDL}$ & $\mathrm{BDL}$ & $\mathrm{BDL}$ & 0.002 & $\mathrm{BDL}$ & BDL & BDL & BDL & BDL & 0.555 & BDL & BDL \\
\hline $\mathrm{Fe}^{\mathrm{b}} 0.700$ & 1.441 & 4.64 & 2.13 & 1.147 & 1.208 & 0.671 & 2.06 & 6.63 & 3.04 & 1.63 & 1.73 & 0.96 \\
\hline
\end{tabular}

bUSEPA, 2011, L = leaves, $\mathrm{R}=$ roots, $\mathrm{F}=$ flowers

\section{Conclusion}

This study gives an evaluation that chosen plants can be used as cancer prevention agents. Antioxidant properties and phytochemical contents varied among the water and acetone extracts of selected plants. Among these plants, Ajuga bracteosa extricate indicated extremely high antioxidant properties and elevated aggregate phenolic substance. It is demonstrated that flavonoid contents are the significant supporter of the cancer prevention agent properties of these plant extracts. The HRI indicates higher levels of cadmium present in roots and flowers of Calotropis procera and also in flowers of Ajuga bracteosa. The results also indicate that roots of Calotropis procera and flowers of both Calotropis procera and Ajuga bracteosa also exhibit less 
phytochemical constituents and antioxidant activity. Based upon the study outcomes, it is proposed that the users should avoid taking roots and flowers of Calotropis procera and flowers of Ajuga bracteosa to cure ailment. Further study is recommended to find and isolate the potential antioxidants to be used in the drug development

\section{REFERENCES}

[1] Aboul-Enein, A. M., El Baz, F. K, El-Baroty, G. S., Youssef, A. M., Abd El-Baky, H. H. (2003): Antioxidant activity of algal extracts on lipid peroxidation. - Journal of Medical Sciences 3: 87-98.

[2] Acosta, J. A., Faz A, Martinez, S. M. (2010): Identification of heavy metal sources by multivariable analysis in a typical Mediterranean city (SE Spain). - Environmental Monitoring and Assessment 169: 519-530.

[3] Aeyigoro, A. O., Okoh, I. A. (2010): Preliminary phytochemical screening and in vitro antioxidant activities of the aqueous extract of Helichrysu longifolium DC. - BMC Complementary and Alternative Medicine 10: 1-8.

[4] Ahmed, M. K. K., Rana, A. C., Dixit, V. K. (2005): Calotropis species (Ascelpediaceae) a comprehensive review. - Pharmacognosy Magazine 1:48-52.

[5] Ali, K., Artun, F. T., Ozcan, G., Melikoglu, G., Anil, S., Kultur, S., Sutlupinar, N. (2015): In vitro evaluation of antioxidant activity of some plant methanol extracts. Biotechnology and Biotechnological Equipment 6: 1184-1189.

[6] Amari, N. O., Bouzouina, M., Berkani, A., Lotmani, B. (2014): Phytochemical screening and antioxidant capacity of the aerial parts of Thymelaea hirsuta L. - Asian Pacific Journal of Tropic Diseases 4: 104-109.

[7] Angelova, V., Ivanova, R., Delibaltova, V., Ivanov, K. (2004): Bioaccumulation and distribution of heavy metals in fiber crops. - Industrial Crops and Products 19: 197-205.

[8] Aoshima, H., Tsunoue, H., Koda, H., Kiso, Y. (2004): Aging of whiskey increases 1, 1diphenyl-2-picrylhydrazyl radical scavenging activity. - Journal of Food Chemistry 52: 5240-5244.

[9] Archana, B., Dasgupta, N., De, B. (2005): In vitro study of antioxidant activity of Syzygium cumini fruit. - Journal of Food Chemistry 90: 727-733.

[10] ATSDR (2017): The Priority List of Hazardous Substances that Will be the Candidates for Toxicological Profiles. - Agency for Toxic Substances and Disease Registry, Atlanta, Gerogia.

[11] Cao, Y., Chen, A., Jones, R. L., Radcliffe, J., Caldwell, K. L., Dietrich, K. N. (2010): Does background post-natal methyl mercury exposure in toddlers affect cognition and behavior? - Neurotoxicology 31: 1-9.

[12] Carlin, Naujokas, D. J., Bradham, M. F., Cowden, K. D., Heacock, J., Henry, M., Lee, H. F., Thomas, J. S., Thompson, D. J., Tokar, C., Waalkes, E. J., Birnbaum, M. P., Suk, L. S. (2016): Arsenic and environmental health: state of the science and future research opportunities. - Environmental Health Perspectives 124: 890-899.

[13] Dinis, T. C. P., Madeira, V. M. C., Almeida, M. L. M. (1994): Action of phenolic derivates (acetaminophen, salicylate and 5-aminosalycilate) as inhibitors of membrane lipid peroxidation and as peroxyl radical scavengers. - Archives of Biochemistry and Biophysics 315: 161-169.

[14] Farhan, H., Malli, F., Rammal, H., Hijazi, A., Bassal, A., Ajouz, N., Badran, B. (2012): Phytochemical screening and antioxidant activity of Lebanese Eryngium creticum L. Asian Pacific Journal of Tropical Biomedicine 2: 1217-1220.

[15] Galindo, Ikuta, M. F., Zhu, I., Casadesus, X., Jordán, G. (2010): Mitochondrial biology in Alzheimer's disease pathogenesis: Review. - Journal of Neurochemistry 114: 933-945. 
[16] Ghias, U., Rauf, A. (2012): Phytochemical screening and biological activity of the aerial parts of Elaeanus umbellate. - Scientific Research and Assays 7: 3690-3694.

[17] Gulcin, I. (2006): Antioxidant and antiradical activities of Carnitine L. - Life Science. 78: 803-811.

[18] Hazara, B., Biswas, S., Mandal, N. (2008): Antioxidant and free radical scavenging activity of Spondias pinnnata. - BMC Complementary and Alternative Medicine 8: 6375 .

[19] Jing, L., Ma, H., Fan, P., Gao, R., Jia, Z. (2015): Antioxidant potential, total phenolic and total flavonoid contents of Rhododendron anthopogonoides and its protective effect on hypoxia-induced injury in PC12 cells. - BMC Complementary \& Alternative Medicine 15: 287.

[20] Kaithwas, G., Gautam, R., Jachak, S. M., Saklani, A. (2012): Antiarthritic effects of Ajuga bracteosa Wall ex Benth. in acute and chronic models of arthritis in albino rats. Asian Pacific Journal of Tropical Biomedicine 2: 185-8.

[21] Kartikar, K. R., Basu, B. D. (1994): Indian Medicinal Plants. - Sudhindra Nath Basu, Allahabad, pp. 1606-1609.

[22] Katalinic, V., Milo, M., Kulisi, T., Juki, M. (2006): Screening of 70 medicinal plant extracts for antioxidant capacity and total phenols. - Journal of Food Chemistry 94: 550557.

[23] Khan, S., Cao, Q., Zheng, Y. M., Huang, Y. Z., Zhu, Y. G. (2008): Health risks of heavy metals in contaminated soils and food crops irrigated with wastewater in Beijing, China. - Environmental Pollution 152: 686-692.

[24] Klein, B. P., Perry, A. K. (1982): Ascorbic acid and vitamin A activity in selected vegetables from different geographical areas of the United States. - Journal of Food Science 47: 941-948.

[25] Kumaran, A., Karunakaran, R. J. (2006): Antioxidant and free radical scavenging activity of an aqueous extract of Coleus aromaticus. - Journal of Food Chemistry 97: 109-114.

[26] Manore, M., Meyer, L. N., Thompson, J. (2009): Mineral and Exercise. - In: Manore, M., Meyer, L. N., Thompson, J. (eds.) Sport Nutrition for Health and Performance. Thames and Hudson, New York, USA.

[27] Mubashir, H., Yamin, B., Naveed, I. R., Muhammad, I., Sumaira, A., Nida, T., Muhammad, I., Anam, I. (2016): A review of therapeutic potential of Ajuga bracteosa: A critically endangered plant from Himalaya. - Journal of Coastal Life Medicine 4: 918924.

[28] Pham-Huy, L. A., Pham-Huy, C. (2008): Free radicals, antioxidants in disease and health. - International Journal of Biomedical Science 4: 89-96.

[29] Prieto, P., Pineda, M., Aguilar, M. (2006): Spectrophotometric quantitation of antioxidant capacity through the formation of a Phosphomolybdenium complex, specific application to the determination of vitamin E. - Analytical Biochemistry 269: 337-341.

[30] Reimann, C., de Caritat, P. (2005): Distinguishing between natural and anthropogenic sources for elements in the environment: Regional geochemical surveys versus enrichment factors. - The Science of the Total Environment 337: 91-107.

[31] Shahidi, F.,Wanasundara, P. K. J. P. D. (1992): Phenolic antioxidants. - Critical Reviews in Food Science \& Nutrition 32: 67-103.

[32] Shen, X. Y., Isogai, A., Furihata, K., Sun, H. G., Suzuki, A. (1993): Two neo-clerodane diterpenoids from Ajuga macrosperma. - Phytochemistry 33: 887-889.

[33] Suja, P. R. (2018): Medicinal flowers in the management of diabetes mellitus: a review. International Journal of Pharmacognosy and Phytochemical Research 10: 297-302.

[34] Turkdogan, M. K., Kilicel, F., Kara, K., Tuncer, I., Uygan, I. (2002): Heavy metals in soil, vegetables and fruits in the endemic upper gastrointestinal cancer region of Turkey. - Environmental Toxicology and Pharmacology 13: 175-179.

[35] USEPA (2011): Risk-Based Concentration Table. - Unites States Environment Agency, Washington, DC. Retrieved on Nov. 15, 2011. 
[36] Uttara, B., Singh, A. V., Zamboni, P., Mahajan, R. T. (2009): Oxidative stress and neurodegenerative diseases: a review of upstream and downstream antioxidant therapeutic options. - Current Neuropharmacology 7: 65-74.

[37] Wang, L. Y., Zhifeng, N., Junfeng, C., Jingy, W. (2009): Characterization, ecological risk assessment and source diagnostics of polycyclic aromatic hydrocarbons in water column of the yellow River Delta, one of the most plenty biodiversity zone in the world. - Journal of hazardous materials 169: 460-465.

[38] Wang, Y., Zhao, C., Li, J., Liang, Y., Yang, L., Liu, J., Ma, Z., Wu, L. (2018): Evaluation of biochemical components and antioxidant capacity of different kiwifruit (Actinidia spp.) genotypes grown in China. - Biotechnology \& Biotechnological Equipment 32: 558-565.

[39] Wojdyłoa, A., Oszmiańskia, J., Czemerysb, R. (2007): Antioxidant activity and phenolic compounds in 32 selected herbs. - Journal of Food Chemistry 105: 940-949.

[40] Yu, L., Haley, S., Perret, J., Harris, J. W., Qian, M. (2002): Free radical scavenging properties of wheat extracts. - Journal of Agricultural and Food Chemistry 50: 16191624.

[41] Yu, W., Zhao, Y., Shu, B. (2004): The radical scavenging activities of radix puerariae isoflavanoids, a chemiluminescence study. - Food Chemistry 86: 525-529.

[42] Ziech, D., Franco, R., Pappa, A., Panayiotidis, M. I. (2011): Reactive oxygen species (ROS)-induced genetic and epigenetic alterations in human carcinogenesis. - Mutation Research - Fundamental and Molecular Mechanisms of Mutagenesis 711: 167-173. 